\title{
Implementasi Peraturan Pemerintah Nomor 32 Tahun 1999 Tentang Pelaksanaan Remisi Bagi Nara Pidana Korupsi Di Lapas Kota Mataram
}

\author{
Rahmawati', Maemunah²
}

\begin{abstract}
${ }^{1}$ Pendidikan Pancasila dan Kewarganegaraan, Universitas Muhammadiyah Mataram, rahmawati19@gmail.com
${ }^{2}$ Pendidikan Pancasila dan Kewarganegaraan, Universitas Muhammadiyah Mataram, maemunahabdullah@gmail.com
\end{abstract}

INFO ARTIKEL
Riwayat Artikel:
Diterima: $\quad 20$-Agustus-
2018
Disetujui: $10-S e p t e m b e r-$
2018

Kata Kunci:

implementasi

remisi

narapidana

korupsi

\begin{abstract}
ABSTRAK
Abstrak: Pemberian remisi di Lembaga Permasyarakatan belum menunjukan hasil yang optimal dalam membina napi. Sistem pembinaan dalam lembaga pemasyarakatan secara yuridis belum sesuai dengan amanat Undang-undang remisi. Tujuan penelitian untuk mengetahui implementasi Peraturan Pemerintah Nomor 32 Tahun 1999 Tentang Pelaksanaan Remisi Bagi Nara Pidana Korupsi dan besarnya pengampunan untuk koruptor menurut Peraturan Pemerintah Nomor 32 Tahun 1999 Tentang Pelaksanaan Remisi Bagi Nara Pidana Korupsi di Lapas Kota Mataram. Jenis metode penelitian ini termasuk penelitian empiris dengan pendekatan normatif yuridis. Penelitian dilaksanakan di Lapas Mataram, responden adalah stakeholder di Lapas Kota Mataram. Pengumpulan data menggunakan observasi, interview dan dokumentasi. Analisis data menggunakan analisis model interaktif. Hasil penelitian menunjukkan pelaksanaan remisi bagi nara pidana korupsi di Lapas Kota Mataram telah berjalan secara optimal, hal tersebut terlihat dari terjadi tren pemberian remisi bagi tahanan di Lapas Kota Mataram mengalami fluktuasi dan diantara nara pidana tersebut, juga diberikan pada pelaku tindak pidana korupsi. Jenis remisi berupa remisi umum sebanyak 543 nara pidana, remisi khusus sebanyak 51 nara pidana, dan remisi tambahan sebanyak 636 nara pidana, yang dilakukan berdasarkan Peraturan Pemerintah Nomor 32 Tahun 1999 Tentang Pelaksanaan Remisi Pasal 34, Pasal 36, Pasal 41, Pasal 42A, dan Pasal 43.

Abstract: The remission of Community institutions has not shown optimal results in the building of the Napi. The construction system in a juridical institution is not yet in accordance with the mandate of the Remission Act. Research objectives to know the implementation of Government Regulation No. 32 the year 1999 on the implementation of remission for criminal corruption and the magnitude of forgiveness for the corrector according to government regulation number 32 the year 1999 on the implementation of remission For criminal corruption in Mataram city Lapas. This type of research method includes empirical research with juridical normative approaches. The study was conducted in Mataram prison, the respondent is a stakeholder in Mataram City Lapas. Data collection using observations, interviews, and documentation. Analyze data using interactive model analysis. The results of the study showed the implementation of remission for criminal corruption in Mataram City prison has been running optimally, it is seen from the trend of remission of prisoners in Mataram City Lapas have fluctuation and between Nara Criminal acts, are also given to corruption perpetrators. This type of remission is a general remission of 543 criminal, special remission as many as 51 criminal, and additional remission of 636 criminal, which is conducted based on government regulation number 32 the year 1999 about the implementation of remission article 34, article 36, article 41, Article 42A, and section 43 .
\end{abstract}

\section{A. LATAR BELAKANG}

Korupsi merupakan sebuah kejahatan luar biasa (extra ordinary crime) sekaligus merupakan kejahatan yang sulit dicari penjahatnya (crime without offender), karena korupsi berada pada wilayah yang sulit untuk ditembus. Korupsi bukan hanya sekedar merugikan keuangan negara, tetapi juga berpotensi merusak sendisendi kehidupan sosial dan hak-hak ekonomi rakyat. Apabila korupsi adalah sebuah kejahatan luar biasa yang dapat disebut sebagai extra ordinary crime, maka upaya pemberantasannya bersifat luar biasa, atau harus dilakukan dengan cara-cara yang berbeda dan diluar kelaziman penanggulangan kejahatan lainnya. Karena sifat luar biasanya inilah kemudian dibuatkan aturan yang eksklusif (khusus) yaitu Undang-Undang Nomor 31 Tahun 1999 tentang Pemberantasan Tindak Pidana Korupsi sebagaimana telah diubah dengan UndangUndang Nomor 20 Tahun 2001 tentang Perubahan atas Undang-Undang Nomor 31 Tahun 1999 tentang Pemberantasan Tindak Pidana Korupsi[1], lembaga pengadilan yang mengadilinya juga dibuatkan secara 
khusus, yakni Pengadilan Tindak Pidana Korupsi (TIPIKOR) yang diatur dalam Pasal 53 Undang-Undang Nomor 30 Tahun 2002 tentang Komisi Pemberantasan Tindak Pidana Korupsi, bahkan dibuatkan juga lembaga eksklusif yang ditugaskan khusus untuk menyelidiki dan menyidiknya, yakni Komisi Pemberantasan Korupsi (KPK) yang diatur dalam Undang-Undang Nomor 30 Tahun 2002 Komisi Pemberantasan Tindak Pidana Korupsi.

Sebagaimana yang diatur dalam Pasal 4 Keppres No. 174 Tahun 1999 tentang Remisi, disebutkan bahwa Bagi napi yang telah menjalani pidana 6 sampai 12 bulan diberikan remisi 1 bulan, untuk yang lebih 12 bulan dapat 2 bulan, bagi yang sudah menjalani tahun kedua dapat 3 bulan, tahun ketiga 4 bulan, tahun keempat dan kelima dapat 5 bulan, tahun keenam dan seterusnya dapat 6 Bulan setiap tahunnya. Secara hukum Remisi adalah pengurangan masa menjalani pidana yg diberikan kepada narapidana dan anak pidana yang memenuhi syarat ditentukan dalam peraturan perundang-undangan (pasal 1 ayat 6 PP 32 tahun 1999 tentang syarat dan tata cara pelaksanaan Hak warga binaan).Setiap Narapidana dan Anak pidana berhak mendapatkan Remisi (Pasal 34 ayat 1angka 6 PP 99 tahun 2012 tentang syarat dan tata cara pelaksanaan Hak warga binaan Pemasyarakatan). Dari defenisi tersebut maka dapat dipastikan bahwa remisi adalah hak terpidana karena itu hak ini harus dihormati sebagai bagian dari hak sasasi manusia khususnya hak terpidana karena itu munculnya pendapat bahwa Remisi jangan diberikan kepada pelaku kasus korupsi adalah tindakan yg salah dan tidak memahami aturan secara jelas.

Berdasarkan perundang-undangan di Indonesia pemberian remisi atau pengurangan masa penghukuman merupakan hak narapidana dengan disertai batasan-batasan kondisi khusus yang secara hukum membedakan remisi yang diterima narapidana satu dengan yang lainnya, keberadaannya tidak lepas dengan sistem pemasyarakatan yang merupakansuatu tatanan pembinaan terhadap narapidana, maka remisi merupakan suaturangsangan agar narapidana bersedia menjalani pembinaan untuk merubahperilaku sesuai dengan tujuan sistem pemasyarakatan[2].

Kenyataan yang terjadi di Lapas Kota Mataram, Lembaga Pemasyarakatan belum menunjukkan hasil yang optimal dalam membina Napi, belum ada korelasi yang cukup signifikan antara lamanya sanksi pidana dengan pengurangan jumlah tindak pidana (keberhasilan dalam melakukan pembinaan Napi.) Namun sistem pembinaan dalam lembaga pemasyarakatan, tidak pernah dibenahi secara efektif.

Pelaksaan pemberian remisi di Lapas Klas IIa Mataram di lakukan setelah narapidana narkotika memenuhi syarat yaitu a. Berkelakuan baik; b. Telah menjalani masa pidana lebih dari 6 (enam) bulan dan bersediabekerja sama dengan penegak hukum untuk membantu membongkar perkara tindak pidana yang dilakukannya[3].

Dalam sistem baru pembinaan nara pidana, remisi ditempatkan sebagai motivasi (salah satu motivasi) bagi nara pidana untuk membina diri sendiri. Sebab itu remisi tidak sebagai hak seperti dalam sistem pemasyarakatan, tidak pula sebagai anugrah sebagaimana dalam sistem kepenjaraan, tetapi sebagai hak dan kewajiban nara pidana. Artinya jika nara pidana benar-benar melaksanakan kewajibannya, ia berhak untuk mendapatkan remisi, sepanjang persyaratan yang lain terpenuhi[4].

Secara yuridis formal, payung hukum berkaitan dengan remisi telah dibuat dalam beberapa peraturan, antara lain 1) Undang-Undang RI No.12 Tahun 1995 tentang Pemasyarakatan; 2) Peraturan Pemerintah RI No. 32 Tahun 1999 jo Peraturan Pemerintah RI No. 28 Tahun 2006 tentang Syarat dan Tata Cara Pelaksanaan Hak Warga Binaan Pemasyarakatan; 3) Keputusan Presiden RI No. 174 Tahun 1999 tentang Remisi[5].

Pasal 34 ayat (3) Peraturan Pemerintah RI No. 28 Tahun 2006 tentang Perubahan Atas Peraturan Pemerintah RI No. 32 Tahun 1999 tentang Syarat dan Tata Cara Pelaksanaan Hak Warga Binaan Pemasyarakatan bagi Nara pidana yang dipidana karena melakukan tindak pidana terorisme, narkotika dan psikotropika, korupsi, kejahatan terhadap keamanan negara dan kejahatan hak asasi manusia yang berat, dan kejahatan transnasional terorganisasi lainnya, remisi diberikan oleh Menteri dalam suatu ketetapan menteri setelah mendapat pertimbangan dari Direktur Jendral Pemasyarakatan, apabila memenuhi persyaratan sebagai berikut : Berkelakukan baik; dan Telah menjalani 1/3 (satu per tiga) masa pidana.

Oleh karena itu, tujuan akhir dalam tulisan ini yaitu untuk mengetahui implementasi Peraturan Pemerintah Nomor 32 Tahun 1999 Tentang Pelaksanaan Remisi Bagi Nara Pidana Korupsi dan besarnya pengampunan untuk koruptor menurut Peraturan Pemerintah Nomor 32 Tahun 1999 Tentang Pelaksanaan Remisi Bagi Nara Pidana Korupsi di Lapas Kota Mataram.

\section{B. METODE PENELITIAN}

1. Metode dan pendekatan penelitian

Metode penelitian adalah suatu pendekatan yang digunakan dalam suatu penelitian yang digunakan sebagai dasar mengenai keseluruhan aktivitas peneliti selama kerja penelitian mulai dari persiapan sampai dengan pelaksanaan penelitian[6]. Untuk memecahkan permasalahan penelitian ini, maka metode penelitian yang digunakan adalah jenis penelitian hukum bersifat empiris. Metode penelitian hukum bersifat empiris yakni rancangan penelitian yang dapat dijelaskan atau diartikan sebagai prosedur atau cara memecahkan masalah penelitian dengan memaparkan keadaan objek yang di selidiki, sebagaimana adanya berdasarkan fakta- 
fakta yang actual pada saat sekarang[7]. Dalam penelitian ini pendekatan yang digunakan adalah pendekatan normatif yuridis[8]. Pendekatan normatif yuridis adalah suatu pendekatan yang mempelajari keteraturan dan berfungsinya hukum berdasarkan Undang-Undang atau peraturan yang ada.

Berdasarkan pendapat ahli di atas, maka metode penelitian yang digunakan adalah metode penelitian empiris dengan pendekatan normatif yuridis tentang penerapan pengaturan mengenai remisi menurut Peraturan Pemerintah Nomor 32 Tahun 1999 Tentang Pelaksanaan Remisi Bagi Nara Pidana Korupsi di Lapas Kota Mataram.

\section{Subjek Penelitian}

Subjek penelitian adalah sekumpulan kasus yang perlu memenuhi syarat-syarat tertentu yang berkaitan dengan masalah penelitian[6]. Ahli lain mengemukakan bahwa subjek penelitian adalah sejumlah kasus yang memenuhi seperangkat kriteria[9].

Dalam penelitian kualitatif tidak menggunakan populasi, karena penelitian kualitatif berangkat dari kasus tertentu yang ada pada situasi sosial tertentu dan hasil kajiannya tidak akan diberlakukan ke populasi, tetapi di tranferkan ketempat lain pada situasi sosial yang memiliki kesamaan dengan situasi sosial pada kasusu yang di pelajari. Sampel dalam penelitian kualitatif bukan di namakan responden, tetapi sebagai narasumber, atau partisipan, informan, teman dan guru dalam penelitian. Sampel dalam penelitian kualitatif, juga bukan disebut sampel statistik, tetapi sampel teoritis, karena tujuan penelitian kualitatif adalah untuk menghasilkan teori. Sampel dalam penelitian kualitatif juga di sebut juga sebagai sampel konstruktif, karena dengan dengan sumber data dari sampel itu dapat dikonstruksikan fenomena yang semula masih belum jelas[10].

Dalam penelitian kualitatif, tehnik sampling yang sering digunakan adalah Purposive Sampling dan Snowball Sampling. Seperti telah dikemukakan bahwa, Purposive Sampling adalah tehnik pengambilan sampel sumber data dengan pertimbangan tertentu. Pertimbangan tertentu ini misalnya orang tersebut yang di anggap paling tahu tentang apa yang kita harapkan, atau mungkin dia sebagai penguasa sehingga akan memudahkan peneliti menjelajahi obyek/situasi sosial yang diteliti. Snowball Sampling adalah tehnik pengambilan sampel sumber data, yang pada awalnya jumlah sedikit, lama-lama menjadi besar. Hal ini dikemukakan karena dari jumlah sunber data yang sedikit itu tersebut belum mampu memberikan data yang lengkap, maka mencari orang lain lagi yang dapat digunakan sebagai sumber data. Dengan demikian jumlah sampel sumber data akan semakin besar, seperti bola salju yang menggelinding lama-lama akan menjadi besar[11].

Berdasarkan hal tersebut di atas bahwa penentuan tehnik sampel dalam penelitian menggunakan teknik
PurposiveSampling, teknik PurposiveSampling ini merupakan teknik sampel yang memberikan data yang lebih lengkap dan mereka tersebut adalah Kepala Lapas, Wakil Kepala Lapas dan Staf Lapas, Napi Koruptor di Lapas Kota Mataram.

3. Teknik Pengumpulan Data

Teknik pengumpulan data adalah cara yang digunakan oleh peneliti untuk mengumpulkan data, dalam hal ini adalah proses diperolehnya data dari sumber data, sumber data yang dimaksud berasal dari subjek penelitian[12].

Dalam penelitian ini, data yang dikumpulkan menggunakan metode sebagai berikut:

\section{a. Metode Observasi}

Observasi adalah pengamatan kepada tingkah laku pada suatu situasi tertentu[13]. Pendapat lain mengemukakan bahwa "observasi adalah alat untuk mengumpulkan data berupa tingkah laku tertentu"[14]. Sementara jenis-jenis observasi meliputi observasi partisipatif, yaitu apabila pengobservasi ikut terlibat dalam kegiatan subjek yang sedang diobservasi, sedangkan observasi non partisipatif yaitu apabila pengobservasi tidak ikut terlibat dalam kegiatan subjek yang sedang diobservasi[8].

Dari pendapat tersebut, maka dapat disimpulkan bahwa metode observasi yang digunakan dalam penelitian ini adalah metode observasi partisipatif untuk mengumpulkan data dengan cara mengamati tentang penerapan pengaturan mengenai remisi menurut Peraturan Pemerintah Nomor 32 Tahun 1999 Tentang Pelaksanaan Remisi Bagi Nara Pidana Korupsi Di Lapas Kota Mataram.

\section{b. Metode Wawancara}

Metode wawancara adalah sebuah dialog yang dilakukan oleh pewawancara (Arikunto, 2008: 126). Pendapat lain mengatakan bahwa metode wawancara adalah suatu teknik pengumpulan data yang dilakuka dengan cara tanya jawab antara penanya atau pewawancara dengan responden/penjawab[15].

Dari kedua pendapat ahli di atas, dapat disimpulkan bahwa metode wawancara adalah teknik pengumpulan data dengan cara tanya jawab secara langsung, yang dilakukan oleh pewawancara dengan responden untuk memperoleh informasi yang diinginkan.

Wawancara atau interview terdiri atas beberapa jenis yaitu sebagai berikut:

1. Wawancara testruktur, wawancara testruktur adalah wawancara yang pertanyaan-pertanyaan telah disiapkan seperti menggunakan pedoman wawancara.

2. Wawancara semistruktur, wawancara semistruktur adalah wawancara yang sudah cukup mendalam kareana ada penggabungan antara wawancara yang perpedoman pada pertanyaanpertanyaan yang telah disiapkan dan pertanyaan yang lebih luas dan mendalam dan mengembalikan pedoman yang sudah ada. 
3. Wawancara tidak terstruktur, wawancara tidak terstruktur adalah wawancara yang lebih bebas, lebih mendalam dan menjadikan pedoman wawancara sebagai pedoman umum dan garis-garis besarnya saja[15].

Sehubungan dengan penelitian ini metode wawancara yang digunakan jenis terstruktur yang digunakan untuk mengumpulkan data penerapan pengaturan mengenai remisi menurut Peraturan Pemerintah Nomor 32 Tahun 1999 Tentang Pelaksanaan Remisi Bagi Nara Pidana Korupsi Di Lapas Kota Mataram.

\section{c. Metode Dokumentasi}

Metode dokumentasi yaitu mencari data mengenai hal-hal atau variabel yang berupa catatan, transkrip, buku, surat kabar, majalah, prasasti, notulen raport, lager agenda dan sebagainya[6]. Atas dasar pendapat para ahli tersebut maka yang dimaksud dengan metode dokumentasi adalah "Bentuk catatan mengenai siswa yang telah dicatat, dalam kumpulan tentang keadaan siswa seperti buku induk, rapor, buku pribadi dan sejenisnya”. Metode dokumentasi dalam penelitian ini yaitu data tentang profil Lapas Kota Mataram.

\section{Metode Analisis Data}

Metode analisis data merupakan strategi penelitian untuk memperoleh data yang valid sesuai dengan karatcristik variabel dan tujuan penelitian[16]. Analisis data yang digunakan dalam penelitian ini yaitu analisis deskriptif dengan menggunakan analisis model interaktif. Analisis interaktif terdiri dari tiga alur kegiatan yang terjadi secara bersama yaitu reduksi data, penyajian data dan penarikan kesimpulan, verifikasi[6].

a. Reduksi Data

Reduksi data diartikan sebagai pemilihan, pemusatan pada penyederhanaan, pengabstrakan dan transformasi data kasar yang muncul dari catatancatatan tertulis dilapangan. Data yang direduksi dalam penelitian ini adalah data tentang penerapan pengaturan mengenai remisi menurut Peraturan Pemerintah Nomor 32 Tahun 1999 Tentang Pelaksanaan Remisi Bagi Nara Pidana Korupsi Di Lapas Kota Mataram.

\section{b. Penyajian Data}

Alur penting yang kedua dari kegiatan analisis data adalah penyajian data sebagai kesimpulan informasi tersusun yang memberikan kemungkinan adanya penarikan kesimpulan dan pengambilan tindakan[6]. Data yang disajikan dalam penelitian ini mengenai penerapan pengaturan mengenai remisi menurut Peraturan Pemerintah Nomor 32 Tahun 1999 Tentang Pelaksanaan Remisi Bagi Nara Pidana Korupsi Di Lapas Kota Mataram.

\section{c. Menarik Kesimpulan}

Penarikan kesimpulan hanyalah sebagai suatu bagian konfigurasi yang utuh, kesimpulan-kesimpulan juga diverivikasi selama penelitian berlangsung[6]. Analisis data dalam penelitian ini dilakukan setelah data terkumpul dan diseleksi. Pengolahan data dilakukan dengan menarik simpulan secara induktif.

\section{HASIL DAN PEMBAHASAN}

\section{Implementasi Peraturan Pemerintah Nomor 32 Tahun 1999 Tentang Pelaksanaan Remisi Bagi Nara Pidana Korupsi di Lapas Kota Mataram}

Lembaga Pemasyarakatan (Lapas) adalah tempat untuk melakukan pembinaan terhadap nara pidana dan anak didik pemasyarakatan di Indonesia. Sebelum dikenal istilah Lapas di Indonesia, tempat tersebut disebut dengan istilah penjara. Lembaga Pemasyarakatan merupakan Unit Pelaksana Teknis di bawah Direktorat Jenderal Pemasyarakatan Kementerian Hukum dan Hak Asasi Manusia (dahulu Departemen Kehakiman). Penghuni Lembaga Pemasyarakatan bisa nara pidana (napi) atau Warga Binaan Pemasyarakatan (WBP) bisa juga yang statusnya masih tahanan, maksudnya orang tersebut masih berada dalam proses peradilan dan belum ditentukan bersalah atau tidak oleh hakim. Pegawai negeri sipil yang menangangi pembinaan nara pidana dan tahanan di lembaga pemasyarakatan disebut dengan Petugas Pemasyarakatan, atau dahulu lebih dikenal dengan istilah Sipir penjara.

Konsep pemasyarakatan pertama kali digagas oleh Menteri Kehakiman Sahardjo pada tahun 1962, dimana disebutkan bahwa tugas jawatan kepenjaraan bukan hanya melaksanakan hukuman, namun tugas yang jauh lebih berat adalah mengembalikan orang-orang yang dijatuhi pidana ke dalam masyarakat. Pada tahun 2005, jumlah penghuni Lapas di Indonesia mencapai 97.671 orang, lebih besar dari kapasitas hunian yang hanya untuk 68.141 orang. Maraknya peredaran narkoba di Indonesia juga salah satu penyebab terjadinya over kapasitas pada tingkat hunian Lapas. Sedangakan Rumah Tahanan Negara (disingkat Rutan) adalah tempat tersangka atau terdakwa ditahan selama proses penyidikan, penuntutan, dan pemeriksaan di sidang pengadilan di Indonesia. Rumah Tahanan Negara merupakan unit pelaksana teknis di bawah Kementerian Hukum dan Hak Asasi Manusia (dahulu Departemen Kehakiman).

rutan dan lapas memiliki beberapa persamaan. Kesamaan antara rutan dengan lapas di antaranya, baik rutan maupun lapas merupakan Unit Pelaksana Teknis di bawah Direktorat Jenderal Pemasyarakatan Departemen Hukum dan Hak Asasi Manusia. Selain itu, penempatan penghuni rutan maupun Lapas sama-sama berdasarkan penggolongan umur, jenis kelamin, dan jenis tindak pidana/kejahatan. Sebagai tambahan, berdasarkan Pasal 38 ayat (1) jo. Penjelasan PP No. 27 Tahun 1983 Tentang Pelaksanaan KUHAP, Menteri dapat menetapkan Lapas tertentu sebagai rutan. Kemudian, dengan adanya Surat Keputusan Menteri Kehakiman No. M.04.UM.01.06 Tahun 1983 tentang Penetapan Lembaga Pemasyarakatan Tertentu sebagai Rumah Tahanan Negara, Lapas dapat beralih fungsi menjadi rutan, dan begitu pula sebaliknya (Observasi 12 Desember 2016).

Berdasarkan Pasal 18 ayat (1) PP No. 27 Tahun 1983, di tiap kabupaten atau kotamadya dibentuk rutan. Namun kondisi yang terjadi di Indonesia adalah tidak 
semua kabupaten dan kota di Indonesia memiliki rutan dan lapas, sehingga rutan difungsikan pula untuk menampung nara pidana seperti halnya Lapas. Hal ini juga mengingat kondisi banyak Lapas yang ada di Indonesia, berdasarkan informasi dari berbagai sumber, telah melebihi kapasitas, karenanya terdakwa yang telah menjalani hukuman di rutan, yang seharusnya pindah dari rutan untuk menjalani hukuman ke lapas, banyak yang tetap berada di dalam rutan hingga masa hukuman mereka selesai.

Sedangkan untuk mengurangi kepadatan (over kapasitas) penghuni Lapas Kota Mataram maka warga binaan (nara pidana) harus kerap kali dilaksanakan pemindahan ke Lembaga Pemasyarakatan Balikpapan dan Lembaga Pemasyarakatan Samarinda (khusus narkotika). Di kedua lembaga Pemasyarakatan tersebut para warga binaan pemasyarakatan (nara pidana) yang hukumannya tinggi dapat melakukan kegiatan yang lebih terarah, terprogram, dan lebih memadai.

Menurut Faisal Ramadani Staf data base seksi registrasi lapas bahwa dasar pemberian remisi tersebut menyatakan,

Untuk pemberian remisi syarat yang diberlakukan oleh Lapas Kota Mataram adalah para tahanan telah menjalani hukuman selama 6 bulan, berkelakuan baik atau tidak masuk dalam

Reg. F, Membayar denda dan uang pengganti jika nara pidana tersebut terkait dengan Peraturan Pemerintah nomor 99, Justice Collaboration dan asimilasi di tempat yang ditentukan jika nara pidana tersebut terkait dengan Peraturan Pemerintah nomor 99. Tahanan tidak sedang menjalani $C B$, Tahanan tidak sedang menjalani pidana kurungan dan pidana pengganti, dan telah berkekuatan hukum tetap dan telah dieksekusi oleh jaksa (Wawancara 12 Desember 2016)

Berdasarkan Pasal 1 angka 6 Peraturan Pemerintah No. 32 Tahun 1999 tentang Syarat dan Tata Cara Pelaksanaan Hak Warga Binaan Pemasyarakatan ("PP 32/1999"), remisi adalah pengurangan masa menjalani pidana yang diberikan kepada Nara pidana dan Anak Pidana yang memenuhi syarat-syarat yang ditentukan dalam peraturan perundang-undangan.

Sebagaimana yang disebutkan dalam Pasal 34 ayat (1)Peraturan Pemerintah Nomor 99 Tahun 2012 tentang Perubahan Kedua Atas Peraturan Pemerintah No. 32 Tahun 1999 tentang Syarat dan Tata Cara Pelaksanaan Hak Warga Binaan Pemasyarakatan("PP 99/2012"), setiap nara pidana dan anak pidana berhak mendapatkan remisi (Ibu Nafsiah, Wawancara 12 Desember 2016).

Nara pidana harus membayar denda terlebih dahulu untuk mendapatkan remisi? Untuk menjawab ini, kita perlu mengacu pada syarat-syarat bagi nara pidana dan anak pidana untuk memperoleh remisi yang terdapat dalam Pasal 34 ayat (2) dan (3) PP 99/2012:

Remisi sebagaimana dimaksud pada ayat (1) dapat diberikan kepada Nara pidana dan Anak Pidana yang telah memenuhi syarat:

a. berkelakuan baik; dan

b. $\quad$ telah menjalani masa pidana lebih dari 6 (enam) bulan.
Persyaratan berkelakuan baik sebagaimana dimaksud pada ayat (2) huruf a dibuktikan dengan:

a. tidak sedang menjalani hukuman disiplin dalam kurun waktu 6 (enam) bulan terakhir, terhitung sebelum tanggal pemberian Remisi; dan

b. $\quad$ telah mengikuti program pembinaan yang diselenggarakan oleh LAPAS dengan predikat baik." (Nafsiah, Wawancara 12 Desember 2016).

Selain syarat-syarat yang terdapat pada Pasal 34 PP 99/2012, persyaratan lain juga terdapat dalam Pasal 34A ayat (1) PP 99/2012 yang berbunyi:

"Pemberian Remisi bagi Nara pidana yang dipidana karena melakukan tindak pidana terorisme, narkotika dan prekursor narkotika, psikotropika, korupsi, kejahatan terhadap keamanan negara, kejahatan hak asasi manusia yang berat, serta kejahatan transnasional terorganisasi lainnya, selain harus memenuhi persyaratan sebagaimana dimaksud dalam Pasal 34juga harus memenuhi persyaratan:

a. bersedia bekerja sama dengan penegak hukum untuk membantu membongkar perkara tindak pidana yang dilakukannya;

b. telah membayar lunas denda dan uang pengganti sesuai dengan putusan pengadilan untuk Nara pidana yang dipidana karena melakukan tindak pidana korupsi; dan

c. telah mengikuti program deradikalisasi yang diselenggarakan oleh LAPAS dan/atau Badan Nasional Penanggulangan Terorisme, serta menyatakan ikrar:

1) kesetiaan kepada Negara Kesatuan Republik Indonesia secara tertulis bagi Nara pidana Warga Negara Indonesia, atau

2) tidak akan mengulangi perbuatan tindak pidana terorisme secara tertulis bagi Nara pidana Warga Negara Asing, yang dipidana karena melakukan tindak pidana terorisme."(Bapak Faisal Ramadani, Wawancara 12 Desember 2016).

Berdasarkan ketentuan di atas, terutama Pasal 34A ayat (1) huruf b PP 99/2012, khusus untuk nara pidana yang dipidana karena melakukan tindak pidana korupsi, baru dapat diberikan remisi jika nara pidana yang bersangkutan telah membayar denda dan uang pengganti sesuai dengan putusan pengadilan. Jadi, persyaratan wajib telah membayar denda dan uang pengganti khusus ditujukan kepada pemberian remisi kepada nara pidana kasus korupsi.

Disamping memenuhi persyaratan diatas, persyaratan yang perlu diperhatikan adalah bahwasanya remisi diberikan kepada nara pidana dan anak pidana apabila memenuhi persyaratan melakukan perbuatan yang membantu kegiatan Lembaga Pemasyarakatan, sesuai dengan Pasal 34 ayat (4) Peraturan Pemerintah RI No. 28 Tahun 2006 tentang Perubahan Atas Peraturan Pemerintah RI No. 32 tahun 1999 tentang Syarat dan Tata Cara Pelaksanaan Hak Warga Binaan Pemasyarakatan.

Berdasarkan Pasal 2 Keputusan Presiden RI No. 174 Tahun 1999 tentang Remisi, jenis-jenis remisi pada dasarnya terdiri dari, selengkapnya dapat dilihat dari hasil wawancara berikut. 
1) Remisi umum, yang diberikan pada hari peringatan Proklamasi Kemerdekakan Republik Indonesia tanggal 17 Agustus; dan

2) Remisi khusus, yang diberikan pada hari besar keagamaan yang dianut oleh nara pidana dan anak pidana yang bersangkutan, dengan ketentuan jika suatu agama mempunyai lebih dari satu hari besar keagaman dalalm setahun, maka yang dipilih adalah hari besar yang paling dimuliakan oleh penganut agama yang bersangkutan (Bapak Nabil Iskandar, Wawancara 17 Desember 2016)

Ketentuan di atas sesuai dengan Pasal 3 ayat (3) Keputusan Presiden RI No. 174 Tahun 1999 tentang Remisi dapat ditambah dengan remisi tambahan apabila nara pidana atau anak pidana yang bersangkutan selama menjalani pidana :

1. Berbuat jasa kepada negara;

2. Melakukan perbuatan yang bermanfaat bagi negara atau kemanusiaan; atau

3. Melakukan perbuatan yng membantu kegiatan pembinaan di Lembaga Pemasyarakatan.

Berdasarkan pasal 1 Peraturan Menteri Hukum dan HAM RI Nomor M.HH-01.PK.02.02 Tahun 2010 diatur pula mengenai Remisi susulan yang terdiri dari :

a. Remisi Umum Susulan, adalah Remisi Umum yang diberikan kepada nara pidana dan anak pidana yang pada tanggal 17 Agustus telah menjalani masa penahanan paling singkat 6 (enam) bulan atau lebih dan belum menerima putusan pengadilan yang mempunyai kekuatan hukum tetap.

b. Remisi Khusus Susulan, adalah Remisi Khusus yang diberikan kepada nara pidana dan anak pidana yang pada hari besar keagamaan sesuai dengan agama yang dianutnya telah menjalani masa penahanan paling singkat 6 (enam) bulan atau lebih dan belum menerima putusan pengadilan yang mempunyai kekuatan hukum tetap.

Pada dasarnya Remisi diatur di dalam UndangUndang RI No.12 Tahun 1995 tentang Pemasyarakatan Pasal 14 huruf i, yang diperkuat dengan kehadiran Keputusan Presiden RI No. 174 Tahun 1999 tentang Remisi yang menjelaskan tentang tiga jenis remisi, yaitu:

1. Remisi umum;

2. Remisi khusus; dan

3. Remisi tambahan.

Didalam Peraturan Pemerintah RI Nomor 28 Tahun 2006 ini, pemerintah telah menyadari akan adanya perbedaan perlakukan dan pembinaan terhadap pelaku tindak pidana korupsi dan terorisme mengingat sifat dan ciri khas dari kedua tibdak pidana tersebut. Akibatnya, syarat untuk memperoleh remisi menjadi lebih ketat dan lebih sulit daripada tindak pidana biasa, seorang nara pidana telah berhak untuk memperoleh remisi setelah menjalani pidana penjara minimum enam bulan, untuk nara pidana koruptor dan teroris disyaratkakn harus telah menjalani sepertiga dari pidananya dan mendapat pertimbangan dari Direktur Jendral Pemasyarakatan. Selengkapnya dapat dilihat dari hasil wawancara berikut. Dalam sebuah diskusi yang bertajuk : "Moratorium dan Remisi untuk Koruptor, Legal atau Melanggar Hukum" di Gedung DPR, Jakarta, Kamis 3 Nopember 2011, salah seorang pembicara, Yusril Ihza Mahendra berpendapat bahwa hak remisi ini diatur bukan hanya dalam undang-undang tapi juga konstitusi, konvensi PBB melawan korupsi (UN Convention Against Corruption), Tokyo Rules dan sebagainya. Yusril juga berpendapat bahwa hak remisi ini dalam seluruh peraturan domestik dan internasional yang ada melekat pada narapida. Serta sudah menjadi aturan diseluruh dunia, bahwa hukuman penjara dapat dikurangi atau dipercepat jika nara pidana memiliki kelakuan baik (Bapak Nabil Iskandar, Wawancara 18 Desember 2016)

Ketua Komisi Nasional Hak Asasi Manusia (Komnas HAM), Ifdhal Kasim, menyatakan :

"Remisi pada dasarnya merupakan insentif bagi terpidana untuk menstimulasi agar merubah diri selama ditahanan, secara normatif seorang terpidana sudah dirampas kebebasannya dengan menjalani hukuman. Meski penyebabnya membenarkan pemberian hukuman tersebut, namun setelah masuk ke dalam tahanan mereka tetap mempunyai hak minimal yakni mendapatkan remisi dan atau pembebasan bersyarat. Bila hak mendapatkan itu dicabut, secara otomatis haknya turut dirampas. Jelas tidak benar itu dilakukan atas nama apapun".

Dengan penjabaran norma tersebut di atas yang diperkuat oleh pendapat para pakar tersebut dapat diketahui bahwa perbuatan tindak pidana korupsi memiliki hak konstitusional yang dijamin oleh undangundang sebagaimana disebut di atas. Disisi lain saat ini banyak para pakar yang setuju dengan gagasan penghapusan remisi bagi nara pidana tindak pidana korupsi, alasannya korupsi telah merusak masa depan bangsa dan tega memiskinkan jutaan rakyat.

Pelaksanaan pemberian remisi merupakan salah satu bentuk pergeseran paradigma pemidanaan dimana remisi merupakan salah satu bentuk pengejawantahan bagaimana agar tahanan dapat berbaur dengan masyarakat, orientasi utamanya bukan lagi pada efek jera. Hal ini yang mendasari berubahnya kata penjara menjadi lembaga pemasyarakatan.

Tabel 1

Data Pemberian Remisi Untuk Lapas Kota Mataram

\begin{tabular}{ccl}
\hline Tahun & $\begin{array}{c}\text { Jumlah Tahan yang } \\
\text { mendapatkan remisi }\end{array}$ & Jenis remisi \\
\hline 2013 & 688 orang & $\begin{array}{l}-\mathrm{RU}=600 \text { orang } \\
-\mathrm{RK}\end{array}=88$ orang \\
\hline 2014 & 552 orang & $\begin{array}{l}-\mathrm{RU}=522 \text { orang } \\
-\mathrm{RK}=30 \text { orang }\end{array}$ \\
\hline 2015 & 524 orang & $\begin{array}{l}-\mathrm{RU}=501 \text { orang } \\
-\mathrm{RK}=23 \text { orang }\end{array}$ \\
\hline 2016 & 594 orang & $-\mathrm{RU}=543$ orang \\
& & $-\mathrm{RK}=51$ orang
\end{tabular}

Sumber : Lapas Kota Mataram Tahun 2017

2. Besar Pengampunan Untuk Koruptor Menurut Peraturan Pemerintah Nomor 32 Tahun 1999 Tentang Pelaksanaan Remisi Bagi Nara Pidana Korupsi di Lapas Kota Mataram

Lapas Kota Mataram merupakan salah satu Unit Pelaksanaan Teknis (UPT) Pemasyarakatan sebagai tempat pembinaan nara pidana yang bernaung di bawah Kantor Wilayah Departemen Hukum dan Hak 
Asasi Manusia Propinsi NTB. Berdasarkan fakta di lapangan Lapas Kota Mataram yang berkapasitas menampung hunian untuk 160 (seratus enam puluh) orang saat ini diisi penghuni sebanyak 240 (dua ratus empat puluh) orang warga binaan pemasyarakatan (nara pidana/tahanan), sehingga melebihi kapasitas yang ada (over kapasitas), sedangkan jumlah petugas yang sangat terbatas.

Uraian tugas dari bagian-bagian maupun seksiseksi yang ada di Lapas Kota Mataram adalah sebagai berikut :

1) Sub Bagian Tata Usaha

Bertugas melakukan urusan tata usaha dan rumah tangga rutan yang terdiri atas :

a) Urusan Kepegawaian dan Keuangan memiliki tugas dalam hal kepegawaian dan keuangan.

b) Urusan Umum mempunyai tugas melakukan surat menyurat, perlengkapan dan rumah tangga rutan.

2) Seksi Bimbingan Nara pidana dan Anak Didik

Bertugas memberikan bimbingan dan pembinaan terhadap nara pidana dan anak didik Pemasyarakatan yang terdiri dari :

a) Sub Seksi Registrasi memiliki tugas dalam melakukan pencatatan, administrasi dan pembuatan statistik, pemberian remisi serta dokumentasi sidik jari nara pidana.

b) Sub Seksi Bimbingan Kemasyarakatan memiliki tugas dalam memberikan bimbingan dan penyuluhan rohani dan memberikan pelatihan olah raga, peningkatan pendidikan dan pengetahuan, program asimilasi, cuti megunjungi keluarga, cuti menjelang bebas dan pembebasan bersyarat, memberikan kesejahteraan dan perawatan bagi nara pidana dan anak didik Pemasyarakatan serta mengurus kesehatannya.

3) Seksi Kegiatan Kerja

Bertugas memberikan petunjuk dan bimbingan kegiatan kerja bagi nara pidana yang terdiri atas :

a) Sub Seksi Bimbingan Kerja dan Pengelolaan Hasil Kerja mempunyai tugas yang meliputi memberikan bimbingan dan pelatihan kerja kepada nara pidana serta mengelola hasil dari pekerjaan tersebut.

b) Sub Seksi Sarana Kerja mempunyai tugas dalam mempersiapkan fasilitas dan sarana kerja.

4) Seksi Administrasi Keamanan dan Tata Tertib terdiri dari:
a) Sub Seksi Keamanan mempunyai tugas mengatur jadwal tugas, penggunaan perlengkapan dan pembagian tugas pengamanan.

b) Sub Seksi Pelaporan dan Tata Tertib mempunyai tugas menerima laporan harian dan berita acara dari satuan pengamanan yang bertugas serta mempersiapkan laporan berkala di bidang keamanan dan penegakan tata tertib.

5) Kesatuan Pengamanan Lembaga Pemasyarakatan

Kesatuan Pengamanan Lembaga Pemasyarakatan (KPLP) terdiri dari petugas pengamanan yang Mempunyai tugas menjaga keamanan dan ketertiban rutan. Dalam Lapas Kota Mataram terdapat 41 (empat puluh satu) orang pegawai yang terdiri dari 35 (tiga puluh lima) orang pegawai pria dan 6 (enam) orang.
Besar Pengampunan untuk Koruptor Menurut Peraturan Pemerintah Nomor 32 Tahun 1999 Tentang Pelaksanaan Remisi Bagi Nara Pidana Korupsi di Lapas Kota Mataram dapat diuraikan berikut:

"Dampak pemberlakuan Peraturan Pemerintah Nomor 32 Tahun 1999 Tentang Pelaksanaan Remisi terhadap nara pidana akan lebih lama menjalani masa hukuman karena tanpa remisi. Sementara mengenai pengetatan pemberian remisi apakah sudah ketat, kalau untuk semangat anti rasuah (Tindak Pidana Korupsi) sudah tepat akan tetapi di sisi lain harus sesuai dengan kaidah hukum yang benar, karena tidak boleh PP No. 99 Tahun 2014 bertentangan dengan UU No. 12 Tahun 1995 sesuai dengan asas hukum Lex superiori derogat lex inferioribahwa secara hierarkis suatu peraturan perundang-undangan tidak boleh bertentangan dengan peraturan peraturan perundangundangan yang lebih tinggi (Bapak Faisal Ramadani, Wawancara 19 Desember 2016).

Jumlah narapidana yang ada di Lapas Mataram, cukup banyak mencapai 847 narapidana.

Pada bulan Juli 2015, Lapas Kota Mataram, mengungkapkan, penghuni Lapas sebelumnya sebanyak 847. Terdiri atas napi kasus pidana umum 606 orang, napi anak 115, dan Tindak Pidana Korupsi (Tipikor) 106 orang yang dapat remisi 534 orang. Empat orang di antaranya dinyatakan bebas. Keempat orang tersebut merupakan tahanan pidana umum. Dikatakan, pemberian remisi didasarkan pada undangundang. Jadi, sesuai undang-undang, remisi itu merupakan hak para napi jika memenuhi syarat, katanya. Dia menambahkan, khusus terpidana korupsi, dari 15 yang diusulkan hanya 3 yang mendapatkan remisi (Bapak Faisal Ramadani, Wawancara 19 Desember 2016).

Dengan adanya pemberian remisi tersebut menandakan bahwa pemberian remisi bagi nara pidana tindak pidana khusus seperti korupsi cukup ketat. Dari sisi efektivitas maka tentunya para para pelaku tindak pidana khusus harus lebih bisa bermasyarakat dan kooperatif dalam membantu petugas untuk membongkar tindak pidana yang dilakukannya. Masalah efektifitas penerapan PP No. 9 Tahun 2012 cukup membuat para terpidana untuk lebih termotivasi dalam berkelakuan baik akan tetapi di sisi lain keberadaan PP ini menurut Faisal Ramadhani masih kurang efektif dalam hal pembinaan.

Spirit penegakan hukum kita masih berorientasi pada hal-hal yang sifatnya represif, keberadan PP No 99 Tahun 2012 bukanlah solusi dalam memberikan efek jera kepada para pelaku tindak pidana khusus, justru di sisi lain akan menimbulkan persoalan hukum baru karena adanya pergeseran paradigma pemidanaan dan bertentangan dengan aturan hukum yang lain.

Lembaga Pemasyarakatan sebagai ujung tombak pelaksanaan pengayoman merupakan tempat untuk menapai tujuan pemidanaan melalui pendidikan rehabilitasi dan reintegrasi. Remisi diberikan kepada warga binaan Pemasyarakatan yang berkelakuaan baik selama menjalani masa pidananya dengan aturan waktu yang ditentukan oleh peraturan undang-undang di Lembaga Pemasyarakatan yang merupakan wujud 
darihasil pembinaan yang dilakukan oleh Lembaga Pemasyarakatan.

Kedudukan remisi dalam tujuan pemidanaan dalam sistem Pemasyarakatan merupakan sarana untuk memotivasi dan mendidik warga binaan agar berkelakuan baik selama menjalani masa pidananya sehingga sete;ah bebas nanti dapat diterima kembali kedalam masyarakat dengan baik.

Data pemberian remisi untuk lapas Kota Mataram yaitu sebagai berikut:

\section{Tabel 2}

Pemberian remisi narapidana di Lapas Kota Mataram

\begin{tabular}{clc}
\hline No. & \multicolumn{1}{c}{ Jenis Remisi } & Jumlah \\
\hline 1 & Remisi Umum & 543 orang \\
2 & Remisi Khusus & 51 orang \\
3 & Remisi Tambahan & 636 orang \\
Jumlah & & 1.230 orang \\
\hline
\end{tabular}

Dari data tersebut dapat diamati bahwa jenis remisi yang diberikan oleh Lapas Kota Mataram pada tahun 2016 terhadap nara pidana bervariasi dengan jenis remisi umum, remisis khusus, dan remisi tambahan dengan jumlah 636 orang nara pidana.

Penghitungan lamanya masa menjalani pidana sebagai dasar untuk menetapkan besarya remisi umum dihitung sejak tanggal penahanan sampai dengan hari proklamasi Kemerdekaan RI pada tanggal 17 Agustus. Untuk menghitung lamanya 1 bulan remisi adalah 30 hari. Selengkapnya dapat dilihat dari hasil wawancara berikut.

Pemberian remisi umum kepada warga binaan Lembaga Pemasyarakatan dibagi lagi menjadi remisi umum sebagian dan remisi umum seluruhnya, dimana remisi umum sebagian adalah remisis yang diberikan kepada warga binaan Lembaga Pemasyarakatan namun ia tetap masih menjalankan sisa pidananya,sedangkan remisi umum seluruhnya adalah pemberian remisi dimana banyaknya remisi yang diterima warga binaan menyelesaikan masa pidananya sehingga ia langsung bebas (Bapak Faisal Ramadani, Wawancara 21 Desember 2016)

Pengusulan untuk mendapatkan remisi umum dilakukan oleh kepala Lembaga Pemasyarakatan kepada Kantor Wilayah Kementrian Hukum dan HAM, selambat-lambatnya satu hari sebelum remisi diberikan. Pengusulan remisi umum dilakukan dengan menggunakan formulir R.B.I untuk remisi umum sebagian dan formulir R.B.II untuk remisi seluruhnya. Setelah pengusulan remisi diterima di kantor wilayah Kementrian Hukum dan HAM lalu di ajukan kepada Direktorat Jenderal Pemasyarakatan. Setelah mendapat pertimbangan dari Direktur Jenderal Pemasyarakatan atas nama Menteri Hukum dan HAM mengabulkan pemberian remisi dengan mengeluarkan surat Keputusan Menteri dan dikirim ke Lembaga Pemasyarakatan yang kemudian diumumkan pada hari Proklamasi Kemerdekaan RI pada tanggal 17 Agustus.

Apabila dalam pelaksanaannya, nara pidana yang telah diajukan untuk mendapat remisi umum ternyata tidak mendapatkan remisi, maka nara pidana tersebut diusulkan kembali pada tahun berikutnya untuk mendapatkan remisi. Pengusulan remisi umum dilakukan dengan menggunakan formulir R.B.I untuk remisi umum sebagian dan formulir R.B.II untuk remisi seluruhnya.

Remisi Khusus diberikan kepada warga binaan di Lembaga Pemasyarakatan bertepatan dengan hari besar keagamaan yang dianut oleh warga binaan yang bersangkutan. Dengan ketentuan bahwa bila dalam satu tahun ada lebih dari satu hari besar keagamaan, maka yang dipilih adalah hari besar keagamaan yang paling dimuliakan oleh penganut agama yang bersangkutan.

Perhitungan lamanya masa menjalankan pidana sebagai dasar menetapkan besarnya remisi khusus dihitung sejak tanggal penahanan sampai dengan hari besar keagamaan warga binaan di Lembaga Pemasyarakatan Kota Mataram. Apabila selama menjalani pidana, warga binaan pindah agama, maka remisi diberikan kepada warga binaan yang bersangkutan menurut agama yang dianut pada saat dilakukan pendataan pertama kali.

Pengusulan remisis khusus menggunakan formulir R.K.I untuk remisi khusus sebagian dan formulir R.K.II untuk pengusulan remisi khusus seluruhnya. Untuk pengajuan usul mendapatkan remisi khusus sama dengan remisi umum yakni dilakukan oleh kepala Lembaga Pemasyarakatan kepada Kantor Wilayah Kementrian Hukum dan HAM, selambatlambatnya satu hari sebelum remisi diberikan. Pengusulan remisi khusus dilakukan dengan menggunakan formulir R.K. Setelah pengusulan remisi diterima di kantor wilayah Kementrian Hukum dan HAM lalu di ajukan kepada Direktorat Jenderal Pemasyarakatan. Setelah mendapat pertimbangan dari Direktur Jenderal Pemasyarakatan atas nama Menteri Hukum dan HAM mengabulkan pemberian remisi dengan mengeluarkan surat Keputusan Menteri dan dikirim ke Lembaga Pemasyarakatan. Namun pemberian remisinya diberikan pada saat, selengkapnya dapat dilihat dari hasil wawancara berikut.

a. $\quad$ Setiap hari Raya Idul Fitri bagi Nara pidana dan Anak Pidana yang beragama Islam.

b. Setiap Hari Natal bagi Nara pidana dan Anak pidana yang beragama Kristen.

c. Setiap Hari Raya Nyepi bagi Nara pidana dan Anak Pidana yang beragama Hindu.

d. Setiap Hari Raya Waisak bagi Nara pidana dan Anak Pidana yang beragama Budha (Bapak Lalu Hidayat, Wawancara 23 Desember 2016)

Apabila dalam pelaksanaannya, nara pidana yang telah diajukan untuk mendapat remisi khusus ternyata tidak mendapatkan remisi, maka nara pidana tersebut diusulkan kembali. Pengusulan remisi umum dilakukan dengan menggunakan formulir R.K.T. (Remisi Khusus Tertunda). 
Remisi tambahan diberikan kepada warga binaan di Lembaga Pemasyarakatan selama menjalani pidana, berbuat jasa kepada negara, melakukan perbuatan yang bermanfaat bagi negara atau kemanusiaan atau melakukan perbuatan yang membantu kegiatan pembinaan di Lembaga Pemasyarakatan.

Pemberian Remisi tambahan di Lembaga Pemasyarakatan Kota Mataram, selengkapnya dapat dilihat dari hasil wawancara berikut.

1. $\quad 1 / 2$ (satu per dua) dari remisi umum yang diperoleh pada tahun yang bersangkutan (warga binaan Pemasyarakatan) berbuat jasa kepada negara atau melakukan perbuatan yang bermanfaat bagi negara atau kemanusiaaan.

2. 1/3 (satu per tiga) dari remisi umum yang diperoleh pada tahun yang bersangkutan (warga binaan Pemasyarakatan) melakukan perbuatan yang dapat membantu kegiatan pembinaan di Lembaga Pemasyarakatan Kota Mataram sebagai pemuka (Bapak Lalu Hidayat, Wawancara 23 Desember 2016)

Pengajuan pengusulan remisi tambahan menggunakan formulir R.T.I untuk remisi tambahan sebagian dan formulir R.T.II untuk remisi tambahan seluruhnya. Pengajuan pengusulan remisi tambahan dilakukan bersama-sama dengan remisi umum dan diberikannya pun pada saat pemberian remisi umum yakni dilakukan oleh kepala Lembaga Pemasyarakatan kepada Kantor Wilayah Kementrian Hukum dan HAM, selambat-lambatnya satu hari sebelum remisi diberikan. Pengusulan remisi tambahan dilakukan dengan menggunakan formulir R.T. Setelah pengusulan remisi diterima di kantor wilayah Kementrian Hukum dan HAM lalu di ajukan kepada Direktorat Jenderal Pemasyarakatan. Setelah mendapat pertimbangan dari Direktur Jenderal Pemasyarakatan atas nama Menteri Hukum dan HAM mengabulkan pemberian remisi dengan mengeluarkan surat Keputusan Menteri dan dikirim ke Lembaga Pemasyarakatan yang kemudian diumumkan pada hari Proklamasi Kemerdekaan RI pada tanggal 17 Agustus.

Apabila dalam pelaksanaannya, nara pidana yang telah diajukan untuk mendapat remisi khusus ternyata tidak mendapatkan remisi, maka nara pidana tersebut diusulkan kembali. Pengusulan remisi umum dilakukan dengan menggunakan formulir R.T.T. (Remisi Tambahan Tertunda).

Jumlah narapidana yang telah diberikan remisi di Lapas Kota Mataram.

\section{Tabel 3}

\section{Narapidana yang Diberikan Remisi}

\begin{tabular}{ccll}
\hline Tahun & $\begin{array}{c}\text { Napi } \\
\text { mendapatkan } \\
\text { remisi }\end{array}$ & \multicolumn{1}{c}{ Jenis remisi } \\
\hline 2013 & 688 orang & $-\mathrm{RU}$ & $=600$ orang \\
& & $-\mathrm{RK}$ & $=88$ orang \\
2014 & 552 orang & $-\mathrm{R} \mathrm{U}$ & $=522$ orang \\
& & $-\mathrm{RK}$ & $=30$ orang \\
2015 & 524 orang & $-\mathrm{RU}$ & $=501$ orang \\
& & $-\mathrm{R} \mathrm{K}$ & $=23$ orang \\
2016 & 594 orang & $-\mathrm{RU}$ & $=543$ orang \\
& & $-\mathrm{RK}$ & $=51$ orang \\
\hline
\end{tabular}

Jadi berdasarkan tabel di atas menunjukkan peningkatan pemberian remisi bagi tahanan di Lapas Kota Mataram mengalami fluktuasi dan diantara nara pidana tersebut, juga diberikan pada pelaku tindak pidana korupsi. Tentu hal itu dipengaruhi oleh syarat atau tolok ukur dalam pemberian remisi bagi para tahanan.

Berdasarkan hasil penelitian bahwa pelaksanaan remisi bagi nara pidana korupsi di Lapas Kota Mataram Tahun 2017 telah berjalan secara optimal, hal tersebut terlihat dari terjadi tren pemberian remisi bagi tahanan di Lapas Kota Mataram mengalami fluktuasi dan diantara nara pidana tersebut, juga diberikan pada pelaku tindak pidana korupsi. Jenis remisi berupa remisi umum sebanyak 543 nara pidana, remisi khusus sebanyak 51 nara pidana, dan remisi tambahan sebanyak 636 nara pidana, yang dilakukan berdasarkan Peraturan Pemerintah Nomor 32 Tahun 1999 Tentang Pelaksanaan Remisi Pasal 34, Pasal 36, Pasal 41, Pasal 42A, dan Pasal 43[1].

Hal inilah yang menjadi landasan dan tujuan dari usaha penegakan hukum terutama dalam bidang hukum pidana yakni kebijaksanaan penanggulangan kejahatan di Indonesia agar sesuai dengan yang diharapkan sekaligus politik hukum di Indonesia. Dalam masyarakat yang sedang membangun pembangunan, tentu terdapat perubahan tata nilai yang berpengaruh pada masing-masing lapangan kehidupan. Perubahan tersebut dapat menuju ke arah yang positif maupun kearah yang negatif.

Seiring dengan itu, agar pembangunan dapat berjalan dengan lancar sesuai dengan cita-cita bangsa Indonesia, sudah tentu dalam dalam pembangunan itu memerlukan situasi yang aman dan tertib. Situasi tersebut hanya dapat terwujud apabila masyarakat bersama-sama dengan pemerintah memiliki kesadaran hukum dan taat (tertib hukum) terhadap segala peraturan yang ada.

\section{TEMUAN DAN DISKUSI}

Bangsa Indonesia mencita-citakan terwujudnya Negara yang adil sesuai dengan Pancasila sila ke-5 yakni keadilan sosial bagi seluruh rakyat indonesia. Untuk mewujudkan hal tersebut, peranan pemerintah sangat penting sehingga secara nyata berusaha untuk mewujudkan rakyat Indonesia ke arah yang dicitacitakan. Dalam hal ini salah satunya mencangkup aspek hukum yang berfalsafah pancasila yang tidak dapat ditinggalkan.

Sistem kepenjaraan mengajarkan bahwa tujuan pemidanaan adalah penjeraan, artinya seorang yang melakukan tindak pidana dibuat jera dan tidak melakukan tindak pidana di kemudian hari. Sedangkan sistem pemasyarakatan yang lebih di kenal dengan Lembaga Pemasyarakatan (LAPAS) yaitu sistem pemasyarakatan diselenggarakan dalam rangka membentuk Warga Binaan Pemasyarakatan agar menjadi manusia seutuhnya, menyadari kesalahan, memperbaiki diri, dan tidak mengulangi tindak pidana sehingga dapat diterima kembali oleh 
lingkungan masyarakat, dapat aktif berperan dalam pembangunan, dan dapat hidup secara wajar sebagai warga yang baik dan bertanggung jawab.

Salah satunya dengan pemberian remisi kepada warga binaan. Remisi adalah sebagai pembebasan hukuman untuk seluruhnya atau sebagian dari seumur hidup menjadi hukuman terbatas yang diberikan setiap tanggal 17 Agustus. Dapat dikatakan bahwa remisi merupakan bentuk pengurangan masa hukuman nara pidana yang sedang menjalani proses pembinaan di Lembaga Pemasyarakatan.

Remisi dalam sistem pelaksanaan pidana penjara khususnya yang menyangkut sistem pemasyarakan sangat penting. Hal ini menyangkut masalah pembinaan yang dilakukan oleh para petugas Lembaga Pemasyarakatan (LAPAS) terhadap para nara pidana. Untuk itu dalam sistem pidana penjara di Indonesia, remisi mempunyai kedudukan yang sangat strategis sebab, apabila nara pidana tidak berkelakuan baik (yang merupakan inti keberhasilan pembinaannya) maka tidak dapat diberikan remisi.

Seperti yang dialami oleh Andy nara pidana yang divonis sebagai pemakai yang telah diajukan oleh pihak Lapas untuk mendapatkan remisi tetapi kenyataannya tidak mendapatkan remisi karena dianggap belum memenuhi syarat masa pidana $1 / 3$ dari masa tahanannya, padahal Andy merupakan nara pidana yang dikecualikan terjerat PP No.28 tahun 2006, karena vonisnya pemakai bukan Bandar. Dalam penjelasan PP No.28 tahun 2006, ketentuan peraturan PP ini hanya berlaku bagi tindak pidana narkotika dan psikotropika dengan vonis produsen dan Bandar.

Nara pidana seperti dijelaskan dalam Undang-undang No 12 tahun 1995 pasal 1 (7) tentang pemasyarakatan, yaitu Terpidana yang menjalani pidana hilang kemerdekaan di Lembaga Pemasyarakatan (LAPAS). Artinya bahwa nara pidana dalam menjalani sanksi pidananya berada dalam pembinaan di lembaga Pemasyarakatan.

Sanksi mengandung inti berupa suatu ancaman pidana (strafbedreiging) kepada mereka yang melakukan pelanggaran norma. Sanksi mempunyai tugas agar norma yang sudah ditetapkan itu ditaati dan dilaksanakan. Sanksi merupakan alat pemaksa agar seseorang menaati norma-norma yang berlaku dalam masyarakat

Dalam penjatuhan pidana dikenal dengan teori relatif atau tujuan (verenigingstheorien) yang merupakan salah satu teori yang membenarkan penjatuhan pidana yakni teori ini mencari dasar hukum pidana dalam menyelenggarakan tertib masyarakat dan akibatnya yaitu tujuan untuk prevensi terjadinya kejahatan dengan wujud berbeda-beda, seperti: menakutkan, memperbaiki dtau membinasakan.

Berdasarkan ketentuan pasal 2 dan 3 Keputusan Presiden RI No. 174 Tahun 1999 tentang Remisi, dikenal jenis-jenis/bentuk Remisi yaitu :

1. Remisi Umum, yang diberikan pada hari peringatan Proklamasi Kemerdekaan Republik Indonesia tanggal 17 Agustus; dan

2. Remisi Khusus, yang diberikan pada hari besar keagamaan yang dianut oleh Nara pidana dan Anak Pidana yang bersangkutan, dengan ketentuan jika suatu agama mempunyai lebih dari satu hari besar keagamaan dalam setahun, maka yang dipilih adalah hari besar yang paling dimuliakan oleh penganut agama yang bersangkutan.

3. Remisi tambahan, ditambahkan apabila Nara pidana dan Anak Pidana yang bersangkutan selama menjalani pidana :

1. berbuat jasa kepada negara;

2. melakukan perbuatan yang bermanfaat bagi negara atau kemanusiaan; atau

3. melakukan perbuatan yang membantu kegiatan pembinaan di Lembaga Pemasyarakatan.

Ketentuan lebih lanjut mengenai berbuat jasa dan melakukan perbuatan yang bermanfaat bagi negara atau bagi kegiatan pembinaan di Lembaga Pemasyarakatan ditetapkan dengan Keputusan Menteri Hukum dan Perundang-undangan.

Sebagaimana telah ditentukan dalam UU Keputusan Presiden No.174 Tahun 1999, Besarnya remisi umum yakni :

1. 1 (satu) bulan bagi Nara pidana dan Anak Pidana yang telah menjalani pidana selama 6 (enam) sampai 12 (dua belas) bulan; dan

2.2 (dua) bulan bagi Nara pidana dan Anak Pidana yang telah menjalani pidana selama 12 (dua belas) bulan atau lebih.

Dalam pemberian remisi umum dilaksanakan sebagai berikut :

a. pada tahun pertama diberikan remisi sebagaimana dimaksud dalam ayat (1);

b. pada tahun kedua diberikan remisi 3 (tiga) bulan;

c. pada tahun ketiga diberikan remisi 4 (empat) bulan;

d. pada tahun keempat dan kelima masing-masing diberikan remisi 5 (lima) bulan; dan

e. pada tahun keenam dan seterusnya diberikan remisi 6 (enam) bulan setiap tahun.

f. Sedangkan besarnya remisi khusus adalah :

g. 15 (lima belas) hari bagi Nara pidana dan Anak Pidana yang telah menjalani pidana selama 6 (enam) sampai 12 (dua belas) bulan; dan

h.1 (satu) bulan bagi Nara pidana dan Anak Pidana yang telah menjalani pidana selama 12 (dua belas) bulan atau lebih.

Dalam pemberian remisi khusus dilaksanakan sebagai berikut :

a. pada tahun pertama diberikan remisi sebagaimana dimaksud dalam ayat (1);

b. pada tahun kedua dan ketiga masing-masing diberikan remisi 1 (satu) bulan;

c. pada tahun keempat dan kelima masing-masing diberikan remisi 1 (satu) bulan 15 (lima belas) hari; dan

d. pada tahun keenam dan seterusnya diberikan remisi 2 (dua) bulan setiap tahun.

Besarnya remisi tambahan adalah

a. 1/2 (satu perdua) dari remisi umum yang diperoleh pada tahun yang bersangkutan bagi Nara pidana dan Anak Pidana yang berbuat jasa kepada negara atau melakukan perbuatan yang bermanfaat bagi negara atau kemanusiaan; dan

b. 1/3 (satu pertiga) dari remisi umum yang diperoleh pada tahun yang bersangkutan bagi Nara pidana dan Anak Pidana yang telah melakukan perbuatan yang membantu kegiatan pembinaan di Lembaga Pemasyarakatan sebagai pemuka. 
Keputusan Presiden No 174 tahun 1999 tentang Remisi pasal 7, yaitu :

1. Penghitungan lamanya masa menjalani pidana sebagai dasar untuk menetapkan besarnya remisi umum dihitung sejak tanggal penahanan sampai dengan hari peringatan Proklamasi Kemerdekaan Republik Indonesia.

2. Penghitungan lamanya masa menjalani pidana sebagai dasar untuk menetapkan besarnya remisi khusus dihitung sejak tanggal penahanan sampai dengan hari besar keagamaan yang dianut oleh Nara pidana dan Anak Pidana yang bersangkutan.

3. Dalam hal masa penahanan sebagaimana dimaksud dalam ayat (1) dan ayat (2) terputus, perhitungan penetapan lamanya masa menjalani pidana dihitung dari sejak penahan yang terakhir.

4. Untuk penghitungan sebagaimana dimaksud dalam pasal ini, 1 (satu) bulan dihitung sama dengan 30 (tiga puluh) hari.

5. Penghitungan besarnya remisi khusus sebagaimana dimaksud dalam ayat (2) didasarkan pada agama Nara pidana dan Anak Pidana yang pertama kali tercatat dalam buku register Lembaga Pemasyarakatan.

Dijelaskan pula dalam Keputusan Presiden No 174 tahun 1999 tentang Remisi pasal 8 :

(1) Dalam hal Nara pidana dan Anak Pidana pada suatu tahun tidak memperoleh remisi, besarnya remisi pada tahun berikutnya didasarkan pada remisi terakhir yang diperolehnya.

(2) Penghitungan remisi bagi Nara pidana dan Anak Pidana yang menjalani pidana lebih dari satu putusan Pengadilan secara berturut-turut dilakukan dengan cara menggabungkan semua putusan pidananya.

(3) Pidana kurungan sebagai pengganti pidana denda tidak diperhitungkan didalam penggabungan putusan pidana sebagaimana dimaksud dalam ayat (2).

Dalam Keputusan Presiden No 174 tahun 1999 tentang Remisi pasal 9 dijelaskan mengenai:

(1) Nara pidana yang dikenakan pidana seumur hidup dan telah menjalani pidana paling sedikit 5 (lima) tahun berturut-turut serta berkelakukan baik, dapat diubah pidananya menjadi pidana penjara sementara, dengan lama sisa pidana yang masih harus dijalani paling lama 15 (lima belas) tahun.

(2) Perubahan pidana penjara seumur hidup menjadi pidana penjara sementara sebagaimana dimaksud dalam ayat (1) ditetapkan dengan Keputusan Presiden.

(3) Permohonan perubahan pidana penjara seumur hidup menjadi pidana sementara diajukan oleh Nara pidana yang bersangkutan kepada Presiden melalui Menteri Hukum dan Perundang-undangan.

(4) Ketentuan mengenai tata cara pengajuan permohonan perubahan pidana seumur hidup menjadi pidana penjara sementara sebagaimana dimaksud dalam ayat (3) diatur lebih lanjut dengan Keputusan Menteri Hukum dan Perundangundangan.

Keputusan Presiden No 174 tahun 1999 tentang Remisi pasal 10: Dalam hal pidana penjara seumur hidup telah diubah menjadi pidana sementara sebagaimana dimaksud dalam Pasal 9, maka untuk pemberian remisi berlaku ketentuan sebagaimana dimaksud dalam Pasal 1 sampai dengan Pasal 6. Seperti yang telah kita ketahui bersama bahwa pemidanaan yang diberikan terhadap nara pidana semata-mata atas perbuatan mereka sendiri karena melakukan tindak pidana yang merugikan orang lain. Namun sasaran utama dari pemidanaan itu sendiri tidak semata-mata tanpa tujuan.

\section{E. SIMPULAN DAN SARAN}

Implementasi Peraturan Pemerintah Nomor 32 Tahun 1999 Tentang Pelaksanaan Remisi Bagi Nara Pidana Korupsi di Lapas Kota Mataram yaitu dilakukan setiap tahun, pada tahun 2016 berupa remisi umum sebanyak 543 nara pidana, remisi khusus sebanyak 51 nara pidana, dan remisi tambahan sebanyak 636 nara pidana, yang dilakukan berdasarkan Peraturan Pemerintah Nomor 32 Tahun 1999 Tentang Pelaksanaan Remisi Pasal 34, Pasal 36, Pasal 41, Pasal 42A, dan Pasal 43. Besar pengampunan untuk koruptor menurut Peraturan Pemerintah Nomor 32 Tahun 1999 Tentang Pelaksanaan Remisi Bagi Nara Pidana Korupsi di Lapas Kota Mataram yaitu bagi Narapidana yang dipidana karena melakukan tindak pidana korupsi, diberikan Remisi apabila memenuhi persyaratan meliputi berkelakuan baik; dan telah menjalani $1 / 3$ (satu per tiga) masa pidana, dengan besar pengampunan meliputi. a). Pemberian Remisi Umum; di atas 1/3 (satu per tiga) masa pidana diberikan remisi 1 (stu) bulan setiap tahun. b). Pemberian Remisi Khusus; di atas 1/3 (satu per tiga) masa pidana diberikan remisi 2 (dua) bulan setiap tahun c). Pemberian Remisi Tambahan; di atas $1 / 3$ (satu per tiga) masa pidana diberikan remisi $1 / 2$ (satu per dua) dari remisi umum yang diperoleh pada tahun yang bersangkutan (warga binaan Pemasyarakatan) berbuat jasa kepada negara atau melakukan perbuatan yang bermanfaat bagi negara atau kemanusiaaan.

Untuk menindaklanjuti sehingga kinerja aparat Lapas maka disarankan beberapa instansi, yaitu. 1). Bagi pemerintah, diharapkan dapat memberikan masukan secara nyata dan aplikatif kepada aparat penegak hukum, pelaksana Undang-Undang, Pemerintah maupun masyarakat luas. 2). Diharapakan dapat memberikan sumbangan pemikiran terhadap lembaga-lembaga khususnya pihak kejaksaan. 3). Bagi masyarakat, sebagai sumber informasi dan pengetahuan bagi masyarakat yang belum mengenal akan hukum korupsi. 4). Bagi peneliti, sebagai referensi tambahan bagi mahasiswa yang berminat dalam kajian hukum khususnya masalah penerapan peraturan mengenai remisi menurut Peraturan Pemerintah Nomor 32 Tahun 1999 Tentang Pelaksanaan Remisi Bagi Nara Pidana Korupsi.

\section{UCAPAN TERIMA KASIH}

Penulis mengucapkan terima kasih kepada pihak LPPM Universitas Muhammadiyah Mataram yang senantiasa memberikan saran, masukan, dan dana kepada penulis sehingga artikel ilmiah ini selesai dengan baik dan tepat waktu.

\section{DAFTAR RUJUKAN}

[1] U.-U. R. I. Nomor, "Tahun 1999 tentang 
pemberantasan tindak pidana korupsi," Undang. Nomor, vol. 20, 31AD.

[2] W. Rori, "Kebijakan Hukum Mengenai Syarat Pemberian Remisi Kepada Narapidana Tindak Pidana Korupsi," Lex Crim., vol. 2, no. 7, 2013.

[3] M. Apriansyah, "Tinjauan tentang Pengurangan Pidana (Remisi) Terhadap Pelaku Tindak Pidana Narkotika (Studi di Lapas Klas II A Mataram).” Universitas Mataram, 2018.

[4] C. I. Harsono, Sistem Baru Pembinaan Narapidana. Djambatan, 1995.

[5] P. P. Nomor, "Tahun 1999 Tentang Syarat dan Tata Cara Pelaksanaan Hak Warga Binaan Pemasyarakatan," Tambah. Lembaran Negara RI, Nomor, vol. 3846, 32AD.

[6] A. Suharsimi, "Prosedur Penelitian Suatu Pendekatan Praktik," Jakarta: Rineka Cipta, 2006.

[7] B. N. Arief, Masalah penegakan hukum dan kebijakan hukum pidana dalam penanggulangan kejahatan. Kencana Prenada Media Group, 2007.

[8] H. S. Salim and E. S. Nurbani, "Penerapan Teori Hukum Pada Penelitian Tesis dan Disertasi," Raja Graf. Persada, Jakarta, 2013.

[9] D. Mardalis, Metode penelitian: suatu pendekatan proposal. Bumi Aksara, 1995.

[10] P. Sugiyono, Metode Penelitian Kuantitatif, Kualitatif, dan R\&D. 2013.

[11] A. Zuhriah and S. Mangkoedihardjo, "Comparison Model to Evapotranspiration Bed Using Upflow and Downflow of Domestic Waste," J. Purifikasi, vol. 6, no. 1, pp. 1-6, 2005.

[12] L. J. Moleong, Metodologi penelitian. 1999.

[13] N. Sudjana, Belajar dan Faktor-faktor yang Mempengaruhinya. 2010.

[14] Y. Riyanto, "Metodologi Penelitian Kualitatif dan Kuantitatif." Surabaya: Unesa University Press, 2007.

[15] D. K. Sukardi, Pengantar pelaksanaan program bimbingan dan konseling disekolah. Rineka Cipta, 2000.

[16] A. Furchan, "Pengantar Pendidikan Dalam Penelitian," Surabaya Usaha Nas., 2007. 